\title{
В.Г. СКЛЯР
}

Сумський національний аграрний університет

вул. Кірова, 160, м. Суми, 40021, Україна

\section{ПРИРОДНЕ ПОНОВЛЕННЯ ПРОВІДНИХ ЛІСОУТВОРЮВАЛЬНИХ ВИДІВ НОВГОРОД- СІВЕРСЬКОГО ПОЛІССЯ: РЕАЛІЗОВАНІ ЕКОЛОГІЧНІ НІШІ ТА ЇХНЯ ДИНАМІКА}

К лю ч о в $i$ с ло в а: абіотичні екологічні чинники, фітоіндикація, природне поновлення лісів, Новгород-Сіверське Полісся

Незважаючи на різні підходи до визначення сутності «екологічної ніші», цей термін є одним із основних у теоретичній екології. Загалом він вживається для характеристики ролі та місця видів і популяцій в екосистемі, їхнього взаємозв'язку з іншими живими організмами та вимогливості щодо умов середовища $[4,5,13,15,18,26]$. Грунтовність і значущість даного поняття - одна з причин спрямованості значної кількість досліджень саме на визначення екологічних ніш різних видів та їхніх популяцій [2, 10, 17, 19, 23, 25, 27, 28]. Лісові рослини в цьому плані не є винятком [7-9, 21].

Оскільки екологічна ніша може бути представлена як n-вимірний гіпероб'єм, що охоплює діапазон умов, за яких організм може успішно існувати та розмножуватись, вивчення параметрів реалізованих екологічних ніш провідних лісоутворювальних видів набуває актуальності в дослідженні процесу самопідтримання лісових фітоценозів. Природне поновлення лісів являє собою процес, коли молоде покоління, що формується під їхнім наметом, зазнає суттєвих кількісних та якісних змін, які супроводжуються онтогенетичним розвитком, динамікою розміру особин, їхнім переходом з однієї категорії підросту в іншу та з нижніх ярусів лісу - до верхніх. При цьому змінюється вимогливість рослин до умов місцезростань. Для низки видів дерев доведеним є факт зміни їхньої тіньовитривалості в міру дорослішання [3, 12]. Крім того, перехід особин молодого покоління з нижніх ярусів лісу до верхніх супроводжується і певними змінами в системі внутрішньовидових і міжвидових взаємовідносин [11]. Усе це має наслідком прояви в різних категорій молодого покоління одного виду відмінностей щодо особливостей реалізованої екологічної ніші.

Мета публікації - для кожного з трьох провідних лісоутворювальних видів Новгород-Сіверського Полісся (Pinus sylvestris L., Quercus robur L., (C) В.Г. СКЛЯР, 2013
Acer platanoides L.) методом фітоіндикації низки абіотичних чинників визначити основні характеристики реалізованих екологічних ніш природного поновлення загалом та різних категорій молодого покоління, формування яких відповідає тим чи іншим етапам даного процесу.

\section{Матеріали та методика досліджень}

Дослідженням були охоплені лісові угруповання, які є найбільш репрезентативними для Новгород-Сіверського Полісся. Їх обирали з опорою на результати вивчення стану фіторізноманіття регіону різними науковцями, зокрема, С.О. Мулярчуком, Т.Л. Андрієнко, О.I. Прядко, С.М. Панченком, О.П. Чорноус [1, 14, 16, 22]. Окрім того, дослідження здійснювались і в менш поширених угрупованнях, під наметом яких спостерігається природне поновлення хоча б одного з трьох лісоутворювальних видів (P. sylvestris, $Q$. robur або A. platanoides). У фітоценозах, обраних для вивчення, на облікових ділянках площею 400 м² здійснювали повні геоботанічні описи: для кожного ярусу лісу враховували комплекс кількісних та якісних характеристик, передбачених загальноприйнятими методиками [20].

Загалом стан природного поновлення P. sylvestris, $Q$. robur або A. platanoides досліджували в угрупованнях 25 асоціацій лісової рослинності (табл. 1). Низка цих фітоценозів має природне походження, однак наявні угруповання, формуванню яких передувало створення штучних лісових насаджень. Серед лісів, які репрезентують формації Betuleta pendulae i Querceta roboris, переважають фітоценози природного походження, а з-поміж угруповань формації Pineta sylvestris, навпаки, - лісові культури. Ліси є різними й за віком: в основному це 60-100-річні. Однак в угрупованнях Pinetum (sylvestris) pleuroziosum природне поновлення відзначене під наметом лісів віком $30-110$ років.

ISSN 0372-4123. Ukr. Bot. J., 2014, 71(1) 
Таблиия 1. Представленість різних категорій молодого покоління Pinus sylvestris, Quercus robur, Acer platanoides у лісових угрупованнях Новгород-Сіверського Полісся

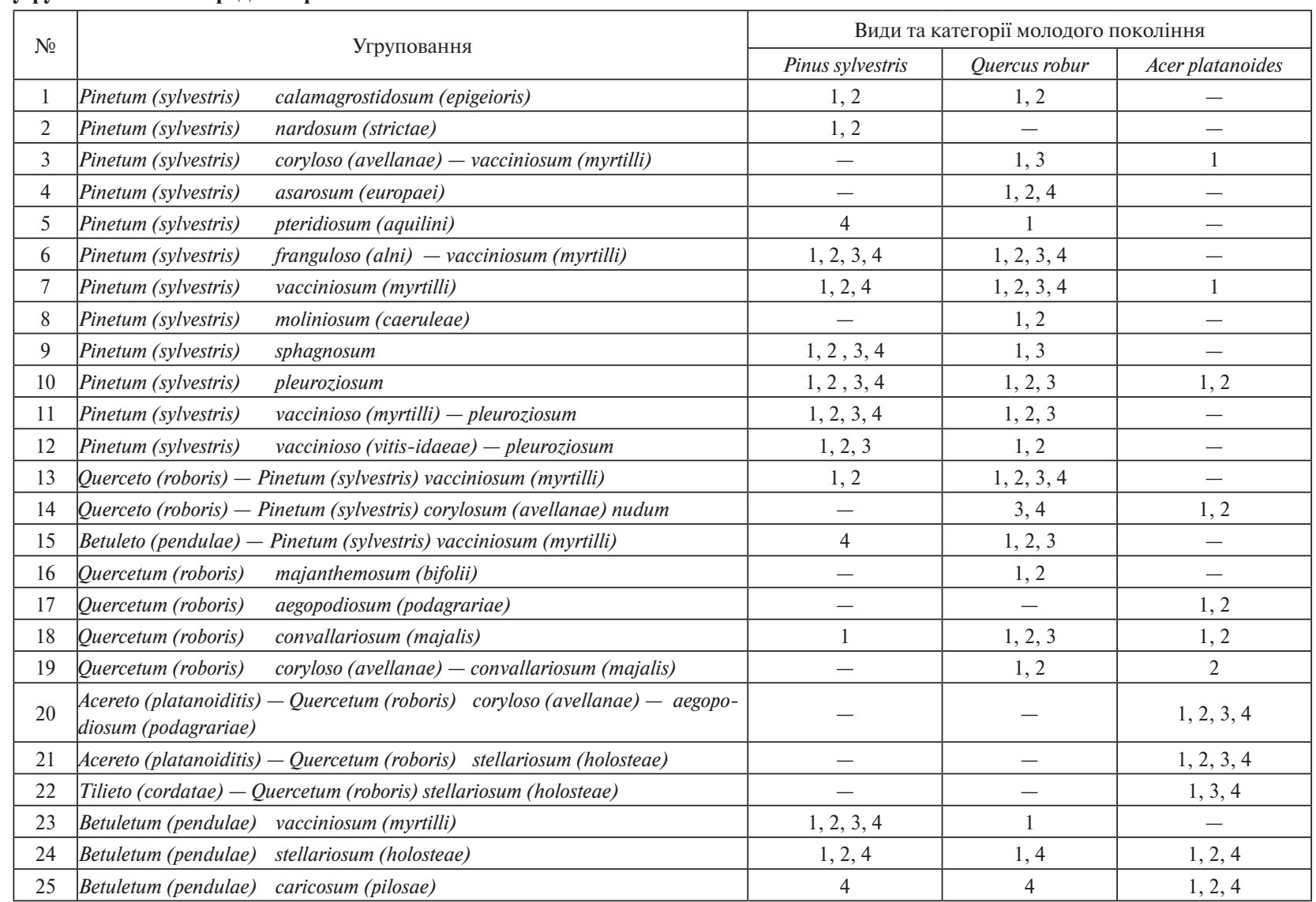

П р и м і т к а: цифрами позначено: 1 - дрібний підріст, 2 - середній, 3 - великий, 4 - молоді дерева ярусу деревостану; «-» позначає відсутність вказаних категорій молодого покоління певного виду в складі даного угруповання.

В усіх досліджуваних фітоценозах оцінювався стан природного поновлення, зокрема, його видовий склад і представленість внутрішньопопуляційних категорій (когорт) молодого покоління: проростків, дрібного, середнього і великого підросту, молодих дерев ярусу деревостану. До проростків відносили рослини перших років вегетації заввишки до 0,1 м. До дрібного підросту - особини, що мають висоту $0,1-0,5$ м і зростають у трав'яно-чагарничковому ярусі. До середнього підросту - рослини, які досягають ярусу підліску та характеризуються висотою 0,5-2,5 м. До великого підросту - особини заввишки 2,5-8,0 м, існування яких пов'язане з верхньою частиною ярусу підліску. До молодих дерев - особини, висотою понад 8,0 м, що досягли ярусу деревостану, однак ще не здатні до генеративного розмноження.

Інформація про наявність під наметом лісів Новгород-Сіверського Полісся різних когорт молодого покоління $P$. sylvestris, $Q$. robur та A. platanoides відображена в табл. 1. Оскільки етап формування проростків відповідає фазі вкрай нестійкого природного поновлення, яка завдяки поширенню насіння досліджуваних видів на значні відстані може ситуативно проявитись у будь-якому фітоценозі, в таблиці наведена інформація тільки щодо представленості за угрупованнями категорій молодого покоління, що відповідають етапам більш сталого природного поновлення: дрібного, середнього та великого підростів, а також молодих дерев ярусу деревостану.

Параметри місцезростань, в яких зафіксоване природне поновлення $P$. sylvestris, $Q$. robur та A. platanoides, визначали методами фітоіндикації з використанням екологічних шкал, розроблених колективом науковців під керівництвом Я.П. Дідуха $[6,24]$. Досліджено такі абіотичні екологічні чинники: водний режим грунту $(H d)$, змінність 
зволоження грунту $(f H)$, кислотність грунту $(R c)$, вміст карбонатів $(C a)$ і нітрогену в грунті $(N t)$, терморежим території $(T m)$, континентальність клімату $(K n)$, кріорежим $(C r)$, освітленість $(L c)$.

Для кожного із зазначених чинників встановлено бальні показники, а також оцінено абсолютний і відносний рівні їхнього варіювання, які, відповідно, характеризують абсолютну та відносну ширину реалізованих еконіш. Абсолютний рівень варіювання визначався як різниця між найбільшою та найменшою величинами бальних показників, що відповідають конкретному чиннику. Відносний рівень варіювання - це виражена у відсотках частка абсолютного розмаху варіювання до кількості ступенів даного чинника в його фітоіндикаційній шкалі. Цей показник знаходили за формулою:

$\left(\left(\operatorname{Max}\left(_{\text {у балах }}\right)-\operatorname{Min}(\right.\right.$ у балах $\left.\left.)\right) / \mathrm{N}_{\text {grade }}\right) \times 100 \%$,

де $\operatorname{Max}($ у балах $)$ - найбільші значення бальних оцінок екологічного чинника,

Min $\left(_{\text {у балах }}\right)$ - найменші його значення,

$\mathrm{N}_{\text {grade }}$ - кількість градацій для даного чинника у фітоіндикаційній екологічній шкалі Я.П. Дідуха [24].

Бальні характеристики та рівень їх варіювання, притаманні кожному з чинників, були базовими показниками для визначення параметрів реалізованої екологічної ніші. Відповідно до мети дослідження іiі характеристики оцінювались для кожного з видів дерев, природного поновлення загалом й окремих когорт молодого покоління.

\section{Результати досліджень та їх обговорення}

Узагальнена інформація про екологічні параметри місцезростань, в яких спостерігається природне поновлення досліджуваних видів, наведена в табл. 2. Встановлено, що в умовах Новгород-Сіверського Полісся параметри реалізованої еко- логічної ніші природного поновлення P. sylvestris, Q. robur i A. platanoides, в основному, охоплюють від двох до чотирьох ключових ступенів фітоіндикаційних шкал Я.П. Дідуха. Зокрема, двом градаціям відповідають умови змінності зволоження та кріорежиму.

У всіх трьох видів природне поновлення представлене в місцезростаннях, які є перехідними від відносно постійного до слабозмінного зволоження або ж мають власне слабозмінне зволоження, а за кріорежимом характеризуються помірними зимами або перехідними від помірних до м'яких. Для цих градацій загальний діапазон варіювання температурних показників найхолоднішого місяця в межах від -14 до $-6^{\circ} \mathrm{C}$.

За умовами терморежиму параметри реалізованої екологічної ніші природного поновлення $P$. sylvestris, $Q$. robur та A. platanoides відповідають суббореальній термозоні та перехідній від суббореальної до неморальної, а за рівнем континентальності - умовам, перехідним від слабоморського клімату до слабоконтинентального або власне слабоконтинентального. На відміну від $P$. Sylvestris і $Q$. robur, поновлення A. platanoides представлене ще й на територіях, рівень радіаційного балансу яких досягає неморальної термозони.

Природне поновлення всіх трьох видів відбувається в місцезростаннях, освітленість яких відповідає трьом ступеням (5-7) фітоіндикаційних шкал Я.П. Дідуха, що характерно для місцезростань з відносною освітленістю від $5 \%$ до повної. Молоде покоління $P$. sylvestris, $Q$. robur та A. platanoides здебільшого представлене там, де забезпеченість грунтів карбонатами також відповідає трьом градаціям фітоіндикаційних шкал (ступені 4-6). Однак середній підріст $A$. platanoides наявний і в

Таблиия 2. Екологічні параметри місцезростань з природним поновленням Pinus sylvestris, Quercus robur, Acer platanoides

\begin{tabular}{|c|c|c|c|c|c|c|c|}
\hline \multirow[b]{2}{*}{ № } & \multirow{2}{*}{$\begin{array}{l}\text { Чинник та його умовне } \\
\text { позначення }\end{array}$} & \multicolumn{2}{|c|}{ Pinus sylvestris } & \multicolumn{2}{|c|}{ Quercus robur } & \multicolumn{2}{|c|}{ Acer platanoides } \\
\hline & & $\begin{array}{c}\text { діапазон показ- } \\
\text { ника, бали }\end{array}$ & $\begin{array}{c}\text { варіювання, } \\
\% \\
\end{array}$ & $\begin{array}{c}\text { діапазон показника, } \\
\text { бали } \\
\end{array}$ & $\begin{array}{c}\text { варіювання, } \\
\% \\
\end{array}$ & $\begin{array}{c}\text { діапазон показника, } \\
\text { бали } \\
\end{array}$ & $\begin{array}{c}\text { варіювання, } \\
\% \\
\end{array}$ \\
\hline 1 & Водний режим грунту $(H d)$ & $12,0-13,8$ & 7,8 & $11,9-13,7$ & 7,8 & $12,0-12,7$ & 3,0 \\
\hline 2 & Кислотність грунту $(R c)$ & $4,9-7,5$ & 17,3 & $4,9-7,5$ & 17,3 & $5,3-7,7$ & 16,0 \\
\hline 3 & Вміст нітрогену в грунті $(N t)$ & $3,7-6,5$ & 25,5 & $3,7-6,1$ & 21,8 & $4,5-7,2$ & 24,5 \\
\hline 4 & Вміст карбонатів у грунті $(\mathrm{Ca})$ & $4,0-6,2$ & 16,9 & $4,1-6,2$ & 16,2 & $4,5-7,8$ & 25,4 \\
\hline 5 & Освітленість $(L c)$ & $5,2-7,4$ & 24,4 & $5,5-7,1$ & 17,8 & $5,0-7,1$ & 23,3 \\
\hline 6 & Змінність зволоження $(f H)$ & $4,5-5,6$ & 10,0 & $4,5-5,7$ & 10,9 & $4,5-5,6$ & 10,0 \\
\hline 7 & Терморежим $(T m)$ & $7,0-8,7$ & 10,0 & $7,0-8,8$ & 10,6 & $7,8-9,0$ & 7,1 \\
\hline 8 & Континентальність клімату $(K n)$ & $8,4-9,4$ & 5,9 & $8,4-9,4$ & 5,9 & $7,8-9,1$ & 7,6 \\
\hline 9 & Кріорежим $(C r)$ & $7,0-8,9$ & 12,7 & $7,0-8,9$ & 12,7 & $7,6-8,8$ & 8,0 \\
\hline
\end{tabular}


місцезростаннях, де вміст карбонатів оцінюється 7 балами і вище. Загалом реалізована екологічна ніша природного поновлення P. sylvestris, Q. robur та A. platanoides відповідає територіям, грунти яких містять $\mathrm{CaO}$ i $\mathrm{MgO}$ у межах 0,05-1,5\%.

За рівнем кислотності грунту та концентрації в ньому нітрогену ліси, в яких формується молоде покоління $P$. sylvestris, $Q$. robur та $A$. platanoides, серед усіх досліджуваних екологічних параметрів, в основному, репрезентують найбільшу кількість ступенів фітоіндикаційних шкал. Їх природне поновлення здебільшого відбувається в місцезростаннях 3 pH грунтів 4,5-6,5 та концентрацією мінерального нітрогену в них 0,05-0,3 \%. При цьому природне поновлення A. platanoides, порівняно з $P$. Sylvestris та $Q$. robur, чіткіше тяжіє до грунтів з меншою кислотністю та вищою забезпеченістю нітрогеном.

Природне поновлення $P$. sylvestris, $Q$. robur та A. platanoides збільшого представлене в місцезростаннях, які $є$ перехідними від сухолісолучного типу зволоження до вологолісолучного. Однак поновлення P. sylvestris та $Q$. robur, на відміну від A. platanoides, є досить успішним ще й у місцезростаннях, які за зволоженістю належать до вологолісолучного типу (для нього характерна зволоженість капілярнопідперто-підвішеною вологою, грунтові води сягають глибини $1-2$ м).

Абсолютні показники ширини реалізованої екологічної ніші природного поновлення у P. sylvestris варіюють від 1,0 (континентальність клімату) до 2,8 бала (вміст нітрогену в грунті). У $Q$. robur від 1,0 (континентальність клімату) до 2,6 бала (кислотність грунту). У A. platanoides від 0,7 (водний режим грунту) до 3,3 бала (вміст карбонатів). Відносна ширина реалізованої еконіші у $P$. sylvestris та $Q$. robur змінюється від 5,9 \% (континентальність клімату) до 21,8-25,5 \% (концентрація нітрогену в грунті). У A. platanoides від 3,0 \% (водний режим грунту) до 25,4 \% (вміст карбонатів).

Наведені узагальнені показники засвідчують наявність видових особливостей у розподілі абсолютних та відносних показників ширини реалізованої екологічної ніші. Це підтверджується i детальнішим аналізом. Її відносна ширина за вмістом нітрогену в грунті та освітленістю зменшується у видів у такій послідовності: $P$. sylvestris $\rightarrow A$. platanoides $\rightarrow Q$. robur. За вміс- том карбонатів у грунті ширина екологічної ніші звужується в такому порядку: A. platanoides $\rightarrow$ $P$. sylvestris $\rightarrow Q$. robur, а за терморежимом $Q$. robur $\rightarrow$ P. sylvestris $\rightarrow$ A. platanoides. Варіювання ширини реалізованої екологічної ніші для чинників водного режиму грунту, його кислотності та кріорежиму відповідає такій послідовності: $P$. sylvestris $=Q$. robur $\rightarrow$ A. platanoides. Перші два види, представлені в ній, не різняться за відносною шириною реалізованої екологічної ніші, тоді як в останнього виду цей показник зменшений. Аналогічно чиннику змінності зволоження відповідає послідовність $Q$. robur $\rightarrow P$. sylvestris $=A$. platanoides, а континентальності клімату $-A$. platanoides $\rightarrow$ $P$. sylvestris $=Q$. robur .

Аналіз свідчить, що природне поновлення досліджуваних видів ( $P$. sylvestris, $Q$. robur i A. platanoides) справді характеризується певними параметрами реалізованої екологічної ніші. При цьому кожному абіотичному екологічному чинникові, що формує гіперпростір еконіші, притаманні ті чи інші значення бальних оцінок, а також абсолютні та відносні величини їх варіювання.

На рівні окремо взятих когорт у досліджуваних видів суттєво зростає частота трапляння випадків, коли ознаки реалізованої екологічної ніші того чи іншого чинника відповідають лише одному зі ступенів фітоіндикаційних шкал (табл. 3). Це характерно для змінності зволоження, терморежиму, континентальності клімату, кріорежиму, освітленості, водного режиму грунтів і навіть для їхньої кислотності, а 3-поміж видів - здебільшого для A. platanoides. У нього формування великого підросту та молодих дерев ярусу деревостану відбувається в місцезростаннях, освітленість яких загалом становить 5,2-5,7 бала, змінність зволоження $-5,0-5,5$, терморежим 8,5-8,8, континентальність климату - 8,3-8,6 бала.

Різним категоріям молодого покоління кожного виду відповідають і певні величини абсолютної та відносної ширини реалізованих екологічних ніш. Значення першої з них у P. sylvestris змінюються від 0,5 (у великого підросту за чинником змінності зволоження) до 2,6 бала (у дрібного, середнього та великого підростів за кислотністю грунту). У $Q$. robur від 0,4 (у молодих дерев за вологістю грунту) до 2,6 бала (у дрібного, середнього та великого підростів за чинником кислотності). 
Таблиця 3. Параметри реалізованої екологічної ніші (в балах) різних категорій молодого покоління провідних лісоутворювальних видів НовгородСіверського Полісся

\begin{tabular}{|c|c|c|c|c|c|c|c|c|c|c|c|c|c|}
\hline \multirow[b]{2}{*}{ № } & \multirow{2}{*}{$\begin{array}{c}\text { Чинник та його } \\
\text { умовне позначення }\end{array}$} & \multicolumn{4}{|c|}{ Pinus sylvestris } & \multicolumn{4}{|c|}{ Quercus robur } & \multicolumn{4}{|c|}{ Acer platanoides } \\
\hline & & \begin{tabular}{|c|} 
дрібний \\
підріст
\end{tabular} & середній & великий & $\begin{array}{l}\text { молоді } \\
\text { дерева }\end{array}$ & $\begin{array}{l}\text { дрібний } \\
\text { підріст }\end{array}$ & середній & великий & $\begin{array}{l}\text { молоді } \\
\text { дерева }\end{array}$ & $\begin{array}{l}\text { дрібний } \\
\text { підріст }\end{array}$ & середній & великий & $\begin{array}{l}\text { молоді } \\
\text { дерева }\end{array}$ \\
\hline 1 & $\begin{array}{c}\text { Водний режим } \\
\text { грунту }(H d)\end{array}$ & $\begin{array}{c}12,0- \\
13,8\end{array}$ & $\begin{array}{c}12,1- \\
13,8\end{array}$ & $\begin{array}{c}12,0- \\
13,7\end{array}$ & $\begin{array}{c}12,2- \\
13,4\end{array}$ & $\begin{array}{c}11,9- \\
13,7\end{array}$ & $\begin{array}{c}11,9- \\
13,3\end{array}$ & $\begin{array}{c}12,3- \\
13,4\end{array}$ & $\begin{array}{c}12,4- \\
12,8\end{array}$ & $\begin{array}{c}12,0- \\
12,7\end{array}$ & $\begin{array}{c}12,0- \\
12,5\end{array}$ & $\begin{array}{c}12,2- \\
12,5\end{array}$ & $\begin{array}{c}12,2- \\
12,5\end{array}$ \\
\hline 2 & $\begin{array}{c}\text { Кислотність грунту } \\
(R c)\end{array}$ & $4,9-7,5$ & $4,9-7,5$ & $4,9-7,5$ & $\begin{array}{r}4,9- \\
6,9\end{array}$ & $4,9-7,5$ & $4,9-7,5$ & $4,9-7,5$ & $5,1-7,3$ & $6,0-7,7$ & $6,5-7,7$ & $7,3-7,6$ & $6,9-7,6$ \\
\hline 3 & $\begin{array}{l}\text { Вміст нітрогену в } \\
\text { грунті }(N t)\end{array}$ & $3,7-6,1$ & $3,7-6,1$ & $3,7-6,1$ & $\begin{array}{r}4,1- \\
5,6\end{array}$ & $3,7-6,1$ & $4,1-6,1$ & $4,2-5,9$ & $4,3-6,1$ & $4,5-7,2$ & $5,1-7,2$ & $5,9-6,6$ & $\begin{array}{c}5,4- \\
6,6\end{array}$ \\
\hline 4 & $\begin{array}{c}\text { Вміст карбонатів у } \\
\text { грунті }(\mathrm{Ca})\end{array}$ & $4,0-5,8$ & $4,0-5,8$ & $4,1-5,8$ & $\begin{array}{c}4,3- \\
5,5\end{array}$ & $4,1-6,1$ & $4,3-5,9$ & $4,3-5,9$ & $4,3-5,9$ & $4,9-6,8$ & $5,2-7,8$ & $5,8-6,8$ & $\begin{array}{c}5,8- \\
6,8\end{array}$ \\
\hline 5 & Освітленість $(L c)$ & $5,8-7,4$ & $5,8-7,4$ & $5,8-6,9$ & $\begin{array}{c}5,7- \\
7,1\end{array}$ & $5,7-7,1$ & $5,7-7,1$ & $5,8-6,9$ & $5,5-6,9$ & $5,0-7,1$ & $5,0-6,4$ & $5,2-5,6$ & $\begin{array}{r}5,2- \\
5,7\end{array}$ \\
\hline 6 & $\begin{array}{c}\text { Змінність } \\
\text { Зволоження }(f H)\end{array}$ & $4,5-5,6$ & $5,0-5,6$ & $5,1-5,6$ & $\begin{array}{c}4,5- \\
5,6 \\
\end{array}$ & $4,5-5,7$ & $4,8-5,7$ & $4,9-5,6$ & $4,9-5,6$ & $4,5-5,6$ & $4,5-5,6$ & $5,0-5,5$ & $\begin{array}{c}5,0- \\
5,5 \\
\end{array}$ \\
\hline 7 & Терморежим (Tm) & $7,0-8,7$ & $7,0-8,7$ & $7,0-8,7$ & $\begin{array}{c}7,5- \\
8,5 \\
\end{array}$ & $7,0-8,8$ & $7,5-8,8$ & $7,5-8,8$ & $7,5-8,6$ & $7,9-9,0$ & $8,4-9,0$ & $8,6-8,8$ & $\begin{array}{c}8,5- \\
8,8 \\
\end{array}$ \\
\hline 8 & $\begin{array}{c}\text { Континентальність } \\
\text { клімату }(K n)\end{array}$ & $8,4-9,4$ & $8,4-9,4$ & $8,4-9,2$ & $\begin{array}{r}8,4- \\
9,0\end{array}$ & $8,4-9,2$ & $8,4-9,4$ & $8,5-9,1$ & $8,4-9,2$ & $7,8-9,1$ & $7,8-8,8$ & $8,3-8,6$ & $\begin{array}{c}8,3- \\
8,6\end{array}$ \\
\hline 9 & Кріорежим $(C r)$ & $7,0-8,4$ & $7,0-8,4$ & $7,0-8,4$ & $\begin{array}{c}7,9- \\
8,9\end{array}$ & $7,0-8,9$ & $7,5-8,5$ & $7,5-8,5$ & $7,8-8,3$ & $7,9-8,8$ & $7,9-8,8$ & $8,3-8,6$ & $7,9-8,6$ \\
\hline
\end{tabular}

У A. platanoides - від 0,2 (у великого підросту за терморежимом) до 2,7 бала (у дрібного підросту за вмістом нітрогену в грунті).

Відносна ширина реалізованих екологічних ніш у $P$. sylvestris змінюється від 3,5\% (у молодих дерев за континентальністю клімату) до $21,8 \%$ (у дрібного, середнього та великого підросту за вмістом нітрогену в грунті). У $Q$. robur від $1,7 \%$ (у молодих дерев за вологістю грунту) до $21,8 \%$ (у дрібного підросту за вмістом нітрогену в грунті). У A. platanoides - від 1,3\% (у молодих дерев за вологістю грунту) до 24,5 \% (у дрібного підросту за вмістом нітрогену в грунті). Порівняння розподілу мінімальних та максимальних показників, що характеризує абсолютну та відносну ширину реалізованих екологічних ніш, здійснене для кожного виду та категорії молодого покоління, підтверджує специфічність і змістовну цінність цих двох характеристик, відсутність між ними повної ідентичносTi.

Характер зміни ширини реалізованої екологічної ніші $P$. sylvestris, $Q$. robur та A. platanoides за етапами природного поновлення ілюструють рисунки $1-3$. У P. sylvestris за більшістю екологічних чинників (водним режимом грунту, його кислотністю, вмістом у ньому нітрогену та карбонатів, а також термо- і кріорежимом) суттєве іiі звуження спостерігається на етапі формування молодих де- рев ярусу деревостану. У A. platanoides реалізовані еконіші великого підросту та молодих дерев ярусу деревостану за всіма досліджуваними чинниками значно поступаються шириною еконішам, шо відповідають рівню дрібного та середнього підросту. У $Q$. robur зменшення ширини екологічної ніші в міру дорослішання молодого покоління характерне для водного режиму грунту, змінності зволоження, термо- та кріорежиму. Загалом у досліджуваних видів при переході від однієї категорії молодого покоління до іншої звуження ширини реалізованої еконіші відзначається в 48,1-51,9\% випадків, iii розширення - в 7,5-22,2 \%. У 25,9-44,4\% випадків ширина ніші не змінюється.

Вважаємо, що природне поновлення буде успішним у тих місцезростаннях, параметри яких відповідають діапазонам перетину реалізованих екологічних ніш усіх основних категорій молодого покоління того чи іншого лісоутворювального виду. В таких місцезростаннях природне поновлення матиме завершений характер, тобто не тільки з'являтимуться молоді рослини в складі певного фітоценозу, а й успішно розвиватимуться і досягатимуть ярусу деревостану з поступовою заміною в ньому рослин попередніх поколінь.

На основі цих міркувань для досліджуваних видів за кожним із провідних екологічних чинників ми порівняли параметри реалізованих екологічних 
口Дрібний підріст $\square$ Середній підріст $\square$ Великий підріст $\mathbf{\square}$ Молодідерева ярусудеревостану

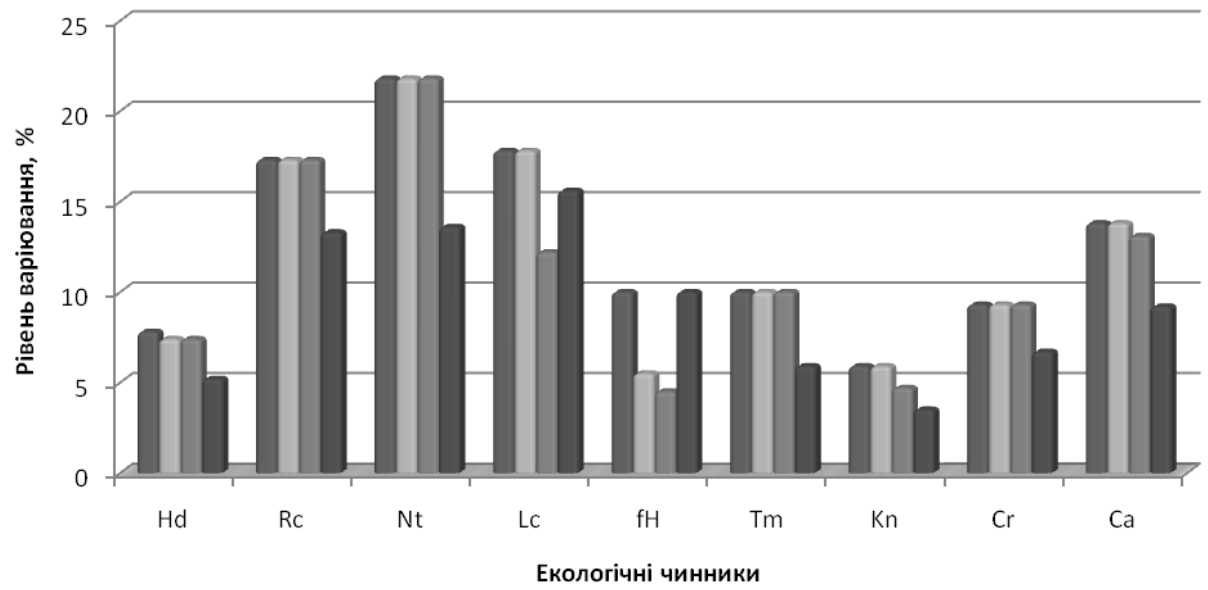

Ф Дрібний підріст

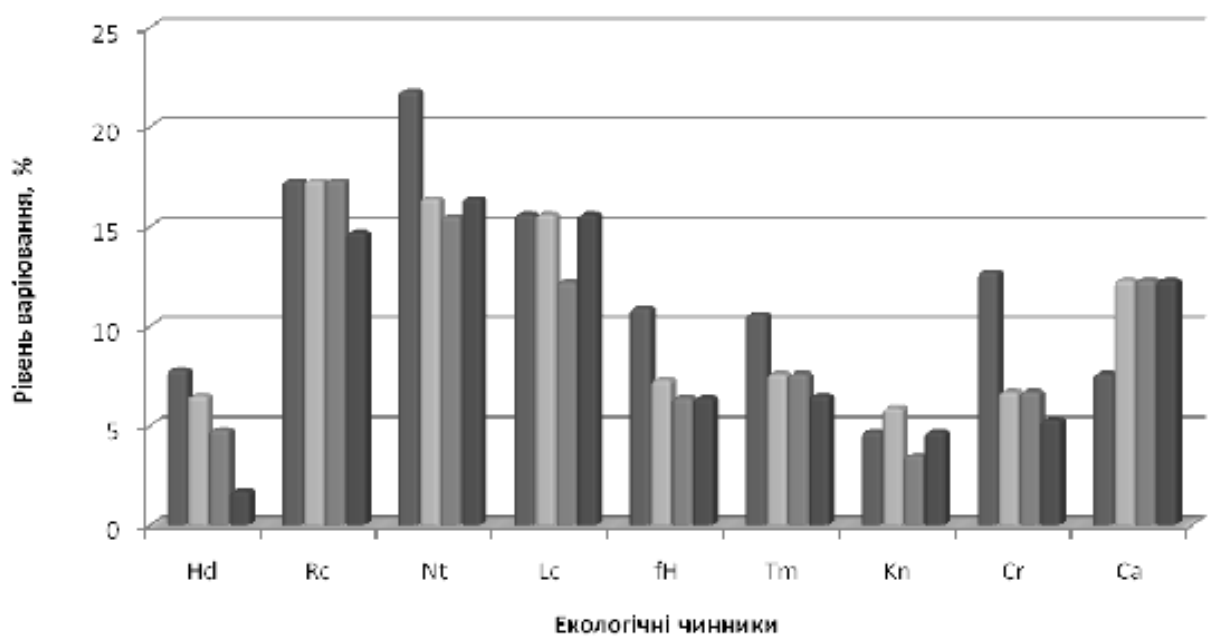

— Дрібний підріст Середній підріст Великий підріст Молодідерева ярусудеревостану

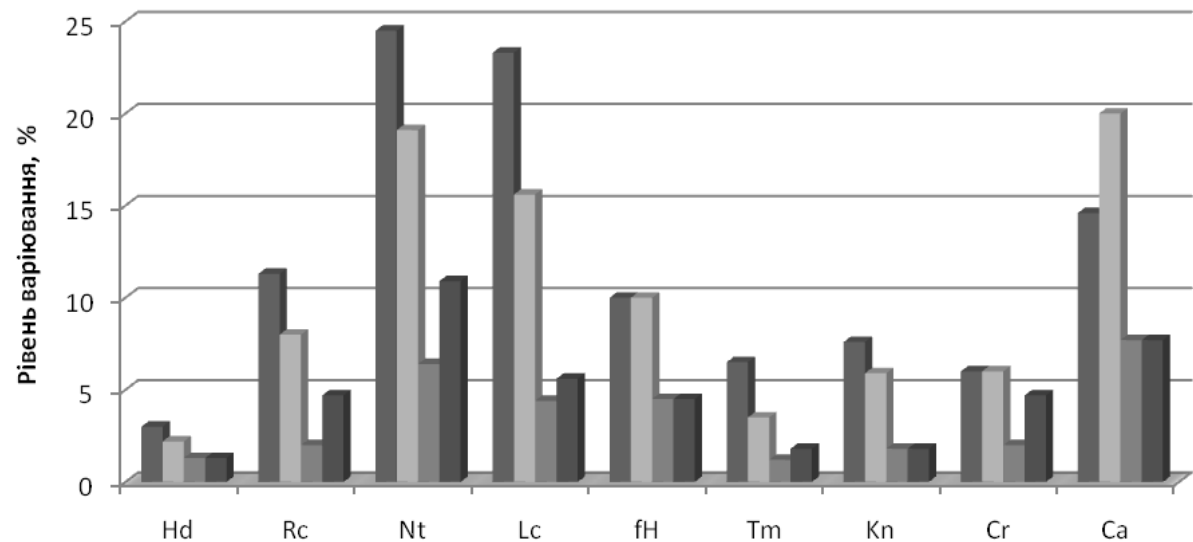

Екологічні чинники
Рис. 1. Відносний рівень варіювання бальних оцінок провідних абіотичних чинників у Pinus sylvestris

Fig. 1. The relative level of variation of score evaluations of leading abiotic factors for Pinus sylvestris

Рис. 2. Відносний рівень варіювання бальних оцінок провідних абіотичних чинників у Quercus robur

Fig. 2. The relative level of variation of score evaluations of leading abiotic factors for Quercus robur

Рис. 3. Відносний рівень варіювання бальних оцінок провідних абіотичних чинників у Acer platanoides

Fig. 3. The relative level of variation of score evaluations of leading abiotic factors for Acer platanoides 


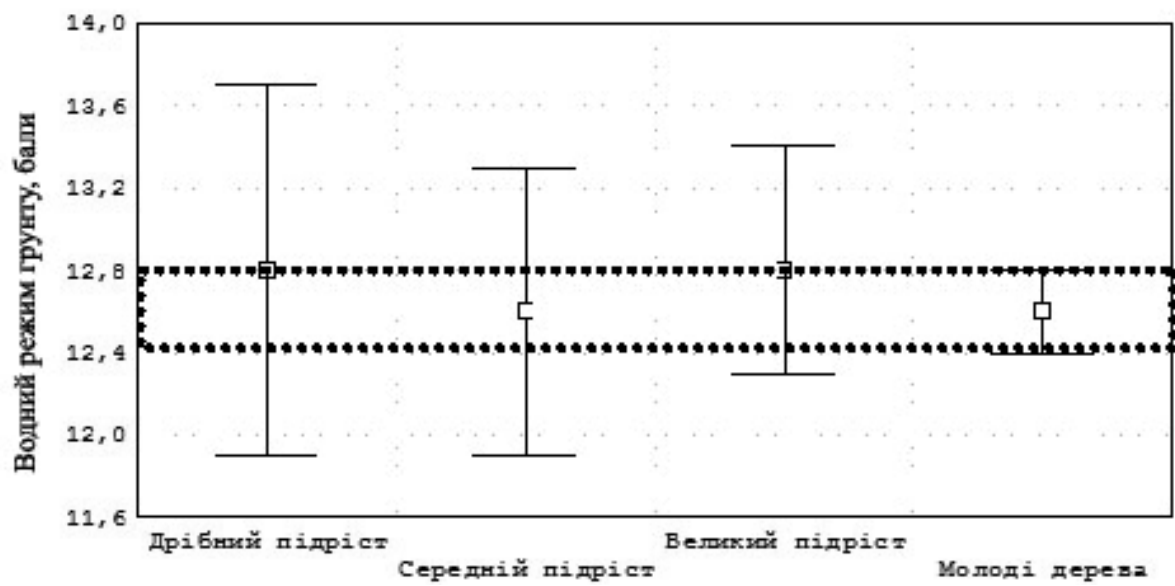

Рис. 4. Параметри реалізованої екологічної ніші за чинником водного режиму грунту, що відповідають різним етапам природного поновлення Quercus robur. У межах зображення позначкою … окреслено екологічний режим, який відповідає перетину реалізованих екологічних ніш усіх основних категорій молодого покоління

Fig. 4. Options of the realized ecological niche factor for soil moisture, which correspond to different stages of forest regrowth of Quercus robur. The ecological regime marked $\cdots$... corresponds to the intersection of the realized ecological niches for all major categories of the the young generations

ніш, які відповідають етапам формування дрібного, середнього, великого підростів та молодих дерев ярусу деревостану (табл. 4, рис. 4). Встановлено, що зазначеним місцезростанням притаманний порівняно вузький діапазон варіювання бальних оцінок екологічних чинників (здебільшого в межах 1-2 ступенів фітоіндикаційних шкал). Абсолютні показники варіювання у P. sylvestris містяться в діапазоні $0,5-2,0$ бала, в $Q$. robur $-0,4-2,2$, у A. platanoides - 0,2-1,0 бала. Відносні ж оцінки ширини еконіш, де може бути завершене природне поновлення, порівняно з аналогічною характеристикою, шо відповідає еконіші даного процесу загалом (див. таблиці 2 і 4), у P. sylvestris є зменшеним у 1,3 (кислотність грунту) - 3,8 (кріорежим) раза, у $Q$. robur - в 1,2 (кислотність грунту) - 4,6 (водний режим грунту) раза, у A. platanoides - у 2,2 (змінність зволоження) $-8,0$ (кислотність грунту) разів.

\section{Висновки}

Параметри реалізованої екологічної ніші природного поновлення можуть бути чітко визначені методами фітоіндикації. Ї̈̈ ознаки (бальні оцінки, абсолютна та відносна ширина) є індивідуальними для лісоутворювальних видів Новгород-Сіверського Полісся. Специфічність реалізованих екологічних ніш проявляється і на рівні окремих етапів природного поновлення одного виду, що свідчить про динамічність еконіш, яка відображає зміну ви-

Таблиия 4. Параметри реалізованої екологічної ніші, сприятливої для всіх основних етапів природного поновлення провідних лісоутворювальних видів в умовах Новгород-Сіверського Полісся

\begin{tabular}{|c|c|c|c|c|c|c|c|}
\hline \multirow{2}{*}{ № } & \multirow{2}{*}{$\begin{array}{l}\text { Чинник та його умовне } \\
\text { позначення }\end{array}$} & \multicolumn{2}{|c|}{ Pinus sylvestris } & \multicolumn{2}{|c|}{ Quercus robur } & \multicolumn{2}{|c|}{ Acer platanoides } \\
\hline & & $\begin{array}{c}\text { діапазон } \\
\text { показника, бали }\end{array}$ & варіювання, \% & $\begin{array}{c}\text { діапазон } \\
\text { показника, бали }\end{array}$ & варіювання, \% & $\begin{array}{c}\text { діапазон } \\
\text { показника, бали }\end{array}$ & $\begin{array}{c}\text { варію- } \\
\text { вання, \% }\end{array}$ \\
\hline 1 & Водний режим грунту $(H d)$ & $12,2-13,4$ & 5,2 & $12,4-12,8$ & 1,7 & $12,2-12,5$ & 1,3 \\
\hline 2 & Кислотність грунту $(R c)$ & $4,9-6,9$ & 13,3 & $5,1-7,3$ & 14,7 & $7,3-7,6$ & 2,0 \\
\hline 3 & Вміст нітрогену в грунті $(N t)$ & $4,1-5,6$ & 13,6 & $4,3-5,9$ & 14,5 & $5,9-6,6$ & 6,4 \\
\hline 4 & Вміст карбонатів у грунті $(\mathrm{Ca})$ & $4,3-5,5$ & 9,2 & $4,3-5,9$ & 12,3 & $5,8-6,8$ & 7,7 \\
\hline 5 & Освітленість $(L c)$ & $5,8-6,9$ & 12,2 & $5,8-6,9$ & 12,2 & $5,2-5,6$ & 4,4 \\
\hline 6 & Змінність зволоження $(f H)$ & $5,1-5,6$ & 4,5 & $4,9-5,6$ & 6,4 & $5,0-5,5$ & 4,5 \\
\hline 7 & Терморежим $(\mathrm{Tm})$ & $7,5-8,5$ & 5,9 & $7,5-8,6$ & 6,5 & $8,6-8,8$ & 1,2 \\
\hline 8 & $\begin{array}{l}\text { Континентальність клімату } \\
(\text { Kn) }\end{array}$ & $8,4-9,0$ & 3,5 & $8,5-9,1$ & 3,5 & $8,3-8,6$ & 1,8 \\
\hline 9 & Кріорежим $(\mathrm{Cr})$ & $7,9-8,4$ & 3,3 & $7,8-8,3$ & 3,3 & $8,3-8,6$ & 2,0 \\
\hline
\end{tabular}


могливості різних категорій молодого покоління до умов місцезростань, а також є засобом зменшення внутрішньовидової конкуренції.

Параметри місцезростань, які відповідають перетину реалізованих екологічних ніш усіх етапів природного поновлення одного виду, сприятливі щодо формування в складі лісового фітоценозу безперервного потоку його поколінь та сталого існування в угрупованні. Їм, як це було показано для $P$. sylvestris, $Q$. robur та A. platanoides, притаманний порівняно вузький діапазон варіювання бальних оцінок провідних екологічних чинників, що, безумовно, суттєво ускладнює перебіг процесу природного поновлення. Перспективним $\epsilon$ доповнення апробованої і висвітленої в цій публікації методики визначення параметрів реалізованої екологічної ніші комплексним популяційним аналізом. При цьому доцільно визначати ознаки місцезростань, де формуються когорти тієї чи іншої категорії молодого покоління, що характеризуються високою щільністю, рівнем віталітету й успішним переходом з нижніх ярусів лісу до верхніх. Це дасть змогу отримати детальні характеристики місцезростань, найсприятливіших для забезпечення сталого існування лісових фітоценозів.

\section{СПИСОК ЛІТЕРАТУРИ}

1. Андрієнко Т.Л., Прядко О.I. Рослинний світ проектованого Деснянсько-Старогутського національного парку / Актуальні пробл. створення ДеснянськоСтарогутського нац. природ. парку та шляхи їх вирішення. - К., 1998. - С. 62-70.

2. Волков И.В. Связь эпиморфологического строения высокогорных растений с объемом реализованной экологической ниши и стратегиями существования в определенных экологических условиях // Вестник ТГПУ. - 2012. - 7, № 12. - С. 132-138.

3. Восточноевропейские широколиственные леса / Р.В. Попадюк, А.А. Чистякова, С.И. Чумаченко и др. М.: Наука, 1994. - 363 с.

4. Гиляров А.М. Популяционная экология. - М.: Издво МГУ, 1990. - 191 с.

5. Джиллер П. Структура сообществ и экологическая ниша. - М.: Мир, 1988. - 184 с.

6. Дідух Я.П., Плюта П.Г. Фітоіндикація екологічних факторів. - К.: Наук. думка, 1994. - 280 с.

7. Зубкова E.В. Изменения соотношения реализованных экологических ниш растений в сообществах при сукцессии // Изв. Самарского науч. центра Рос. акад. наук. - 2009. - 11, № 7. - С. 1634-1639.

8. Кожевников А.П., Годовалов Г.А., Яппарова А.Ф. Экологические ниши популяций рябины обыкновенной в лесопарковой зоне г. Екатеринбурга // Аграрн. вестн. Урала. - 2011. - № 4. - С. 80-81.

9. Комаров А.С., Зубкова Е.В. Динамика распределения экологических ниш в сообществах лесных растений при сукцессии // Математ. биология и биоинформатика. 2012. - 7, № 1. - С. 152-161.

10. Левченко В.Ф., Старобогатов Я.И. Сукцессионные изменения и эволюция экосистем (некоторые вопросы эволюционной экологии) // Журн. общ. биол. - 1990. 51, № 5. - С. 619-631.

11. Лосицкий К.Б. Восстановление дубрав. - М.: Изд-во сельхоз. лит., журн. и плакатов, 1963. - 358 с.

12. Мелехов И.С. Лесоведение. - М.: Лес. пром-сть, 1980. $405 \mathrm{c}$.

13. Миркин Б.М., Розенберг Г.С. Толковый словарь современной фитоценологии. - М.: Наука, 1983. $133 \mathrm{c}$.

14. Мулярчук С.О. Соснові ліси Сумського Полісся // Укр. ботан. журн. - 1970. - 27, № 6. - С. 726-730.

15. Одум Ю. Основы экологии. - М.: Мир, 1975. - 740 с.

16. Панченко С.М. Рослинність Старогутського лісового масиву // Укр. ботан. журн. - 2001. - 58, № 6. С. 684-693.

17. Перевозкин П.П., Гордеев М.И. Экологическая ниша. Томск, 2004. - $20 \mathrm{c}$.

18. Северцов А.С. Механизм возникновения и экологическое значение фундаментальной ниши вида // Экология. 2004. - № 6. - С. 403-409.

19. Селедец В.П. Экологическая ниша ценопопуляций полевицы Триниуса в континентальных районах и на Тихоокеанском побережье России // Бюл. Ботан. сада - Ин-та ДВО РАН. - 2008. - Вып. 2. - С. 19-23.

20. Сукачев В. М., Зонн С. В. Методические указания к изучению типов леса. - М.: Изд-во АН СССР, 1961. $143 \mathrm{c}$.

21. Хлюстов К.Б., Мурачева Л.С., Бедарева О.М. Экологические ниши в лесопарковых экосистемах Калининградской области // Вестн. Саратов. гос. агроун-та. - 2011. - № 7. - С. 39-43.

22. Чорноус О.П. Лісова рослинність Шосткинського геоботанічного району (Сумська область) // Укр. ботан. журн. - 2006. - 63, № 3. - С. 401-409.

23. Charles T., Garten Jr. Multivariate perspectives on the ecology of plant mineral element composition // Amer. Naturalist. - 1978. - 112(985). - P. 533-544.

24. Didukh Ya. P. The ecological scales for the species of Ukrainian flora and their use in synphytoindication. - Kyiv: Phytosociocentre, 2011. - $176 \mathrm{p}$.

25. Hirzel A. H., Hausser J., Chessel D. et al. Ecological-niche factor analysis: how to compute habitat-suitability maps without absence data // Ecology. - 2002. - 83. - P. 20272036.

26. Hutchinson G.E. Concluding remarks // Cold Spring Harbor Symposia on Quantitative Biol. - 1957. - 22. - P. 415427.

27. Townsend $P$. Predicting the geography of species' invasions via ecological niche modeling // Quarterly Rev. Biol. 2003. - 78(4). - P. 419-433.

28. Townsend P., Papeş M., Eaton M. Transferability and model evaluation in ecological niche modeling: a comparison of GARP and Maxent // Ecography. - 2007. - 30(4). P. $550-560$.

Рекомендує до друку

Надійшла 18.02.2013 p.

Я.П. Дідух 


\section{В.Г. Скляр \\ Сумской национальный аграрный университет, Украина

ЕСТЕСТВЕННОЕ ВОЗОБНОВЛЕНИЕ
ЛЕСООБРАЗУЮЩИХ ОСОВНЫХ
СЕВЕРСКОГО ПИДОВ
ЭКОЛОГИЧЕСКИЕ НИШИ И ИХ ДИНАМИКА

На основе использования метода фитоиндикации для Pinus sylvestris L., Quercus robur L. и Acer platanoides L., как ведущих лесообразующих видов Новгород-Северского Полесья, установлены параметры реализованной экологической ниши их естественного возобновления в целом, а также отдельных этапов данного процесса, которым соответствует формирование разных категорий подроста и деревьев яруса древостоя. Для этих когорт молодого поколения выяснен характер динамики показателей реализованных экологических ниш и оценено их наложение, что позволило определить параметры местопроизрастаний, благоприятных для естественного возобновления P. sylvestris, $Q$. robur и A. platanoides в лесах Новгород-Северского Полесья.

Ключ г в ы е сло в а: абиотические экологические факторы, фитоиндикация, естественное возобновление лесов, НовгородСеверское Полесье.
V.G. Skliar

Sumy National Agrarian University

NATURAL REGROWTH OF THE MAIN FORESTFORMING SPECIES OF NOVGOROD-SIVERSKY POLISSYA: REALIZED ECOLOGICAL NICHES AND THEIR DYNAMICS

Using the phytoindication method, parameters for realized ecological niches of natural regrowth were established for the leading forest-forming species of Novgorod-Siversky Polissya, Pinus sylvestris L., Quercus robur L., and Acer platanoides L. Individual stages of the process corresponding to formation of different categories of undergrowth and tree stand tier were defined. For the cohort of young generation, dynamic character of the realized ecological niches was clarified and their superposition was estimated. Parameters of favorable habitats for natural regrowth of $P$. sylvestris, $Q$. robur and A. platanoides in the forests of Novgorod-Siversky Polissya were determined.

Ke y w o rds: abiotic ecological factors, phytoindication, natural forest regrowth, Novgorod-Siversky Polissya.

\section{НОВІ ВИДАННЯ}

Попенко Е.А., Самчук А.І., Гродзинська Г.А. та ін. Еколого-геохімічні дослідження в об'єктах довкілля. Київ: Альфа реклама, 2012. - 150 с.

У цьому науковому виданні викладено результати еколого-геохімічних досліджень об'єктів довкілля природних і техногенних ландшафтів України. Наведено нові дані про закономірності розподілу мікроелементів та їхніх форм у грунтах, поверхневих і підземних водах, рослинності та їх поведінку в трофічному ланцюгу «грунт-розчин-рослина». 